\title{
Overstated Potential for Seagrass Meadows to Mitigate Coastal Ocean Acidification
}

\author{
Bryce Van Dam ${ }^{1 *}$, Christian Lopes ${ }^{2}$, Mary A. Zeller ${ }^{3}$, Mariana Ribas-Ribas ${ }^{4}$, \\ Hongjie Wang ${ }^{5}$ and Helmuth Thomas ${ }^{1}$ \\ ${ }^{1}$ Institute of Carbon Cycles, Helmholtz-Zentrum Hereon, Geesthacht, Germany, ${ }^{2}$ Department of Biological Sciences, Institute \\ of Environment, Florida International University, Miami, FL, United States, ${ }^{3}$ Geochemistry and Isotope Biogeochemistry \\ Group, Department of Marine Geology, Leibniz Institute for Baltic Sea Research, Warnemnde, Germany, ${ }^{4}$ Center for Marine \\ Sensors, Institute for Chemistry and Biology of the Marine Environment, Carl von Ossietzky Universität Oldenburg, \\ Wilhelmshaven, Germany, ${ }^{5}$ Cooperative Institute for Climate, Ocean, and Ecosystem Science, University of Washington, \\ Seattle, WA, United States
}

Keywords: ocean acidification, seagrass, carbonate chemistry, $\mathrm{CO}_{2}$ system calculations, commentary articles

\section{OPEN ACCESS}

Edited by:

Antonio Cobelo-Garcia,

Consejo Superior de Investigaciones Cientificas (CSIC), Spain

Reviewed by: Toni Padin,

Instituto de Investigaciones Marinas (CSIC), Spain

${ }^{*}$ Correspondence:

Bryce Van Dam bryce.dam@hereon.de

Specialty section:

This article was submitted to Marine Biogeochemistry,

a section of the journal

Frontiers in Marine Science

Received: 07 July 2021 Accepted: 11 October 2021 Published: 01 November 2021

Citation:

Van Dam B, Lopes C, Zeller MA,

Ribas-Ribas M, Wang $\mathrm{H}$ and Thomas H (2021) Overstated Potential for Seagrass Meadows to Mitigate

Coastal Ocean Acidification.

Front. Mar. Sci. 8:729992.

doi: 10.3389/fmars.2021.729992
Ricart et al. (2021, R21) explored the potential for seagrass meadows to act as a buffer of coastal ocean acidification (OA). This work relied largely on sensor-based $\mathrm{pH}$ measurements during 29 separate instrument deployments along the California coast, arguing that (1) seagrass aerobic metabolism consistently enhances local $\mathrm{pH}$, and that (2) this OA-amelioration can persist for lengths of up to 21 days. While $\mathrm{pH}$ was often greater in seagrass meadows than in adjacent unvegetated regions, we are concerned with the extent to which this is attributed to seagrass ecosystem metabolism, and the interpretation that this OA-amelioration is sustained over daily and tidal timescales. By incompletely considering alternative explanations for elevated $\mathrm{pH}$, irrespective of seagrass productivity, R21 offers insufficient support of OA-mitigation as a reliable ecosystem service of seagrasses. We therefore see the authors' claim that seagrass ecosystems could be "leveraged as local management tools to mitigate the consequences of OA" as worthy of critical inspection.

First, there is a fundamental issue in $\mathrm{R} 21$ with the mathematical treatment of $\Delta \mathrm{pH}(\Delta \mathrm{pH}=$ $\mathrm{pH}_{\text {seagrass }}-\mathrm{pH}_{\text {nonvegetated }}$ ), stemming from the fact that $\mathrm{pH}$ is on a logarithmic scale. To illustrate this issue, it is a simple fact that a $\Delta \mathrm{pH}$ of 0.1 involves a change in $\left[\mathrm{H}^{+}\right]$that is 10 times larger when starting at $\mathrm{pH}=7$ than at $\mathrm{pH}=8$. This effect is made abundantly clear by the linear relationship between $\mathrm{pH}$ and $\Delta \mathrm{pH}$ (Figure 1A) present in the R21 dataset. As expected, $\mathrm{pH}$ also varies with salinity, with slopes that vary across sites (Figure 1B) and seasons (Figure 5 in R21). Such comparisons of $\Delta \mathrm{pH}$ across sites, seasons, etc., are mathematically inappropriate, when made without also considering $\Delta\left[\mathrm{H}^{+}\right]$(Fassbender et al., 2021). We therefore find the interpretation of $\Delta \mathrm{pH}$ in $\mathrm{R} 21$ to be misleading because it does not consider the impact of initial $\mathrm{pH}$ on the size of $\Delta \mathrm{pH}$.

Next, while we agree that $\mathrm{CO}_{2}$ uptake by seagrasses undeniably increases $\mathrm{pH}$, many other concurrent processes affect the carbonate system, including mixing, aerobic and anaerobic respiration (and coincident alkalinity consumption/production), and air-water $\mathrm{CO}_{2}$ exchange. Of concern, then, is the attribution by $\mathrm{R} 21$ of all positive $\Delta \mathrm{pH}$ values strictly to seagrass photosynthetic activity. We feel that it is only reasonable to attribute positive $\Delta \mathrm{pH}$ values to seagrass photosynthetic activity as the dominant driver when excess dissolved oxygen (DO) is observed, such that $\triangle \mathrm{DO} \%$ is greater than $0\left(\Delta \mathrm{DO} \%=\mathrm{DO} \%_{\text {seagrass }}-\mathrm{DO} \%_{\text {non-vegetated }}\right)$. Tidal mixing between fresh and marine endmembers will also cause changes in $\mathrm{pH}$ independent of seagrass metabolism, as can be seen in the relationships between salinity and $\mathrm{pH}$, with slopes that vary across sites and seasons (Figure 1B). Changes in salinity as small as 0.1 are associated with 

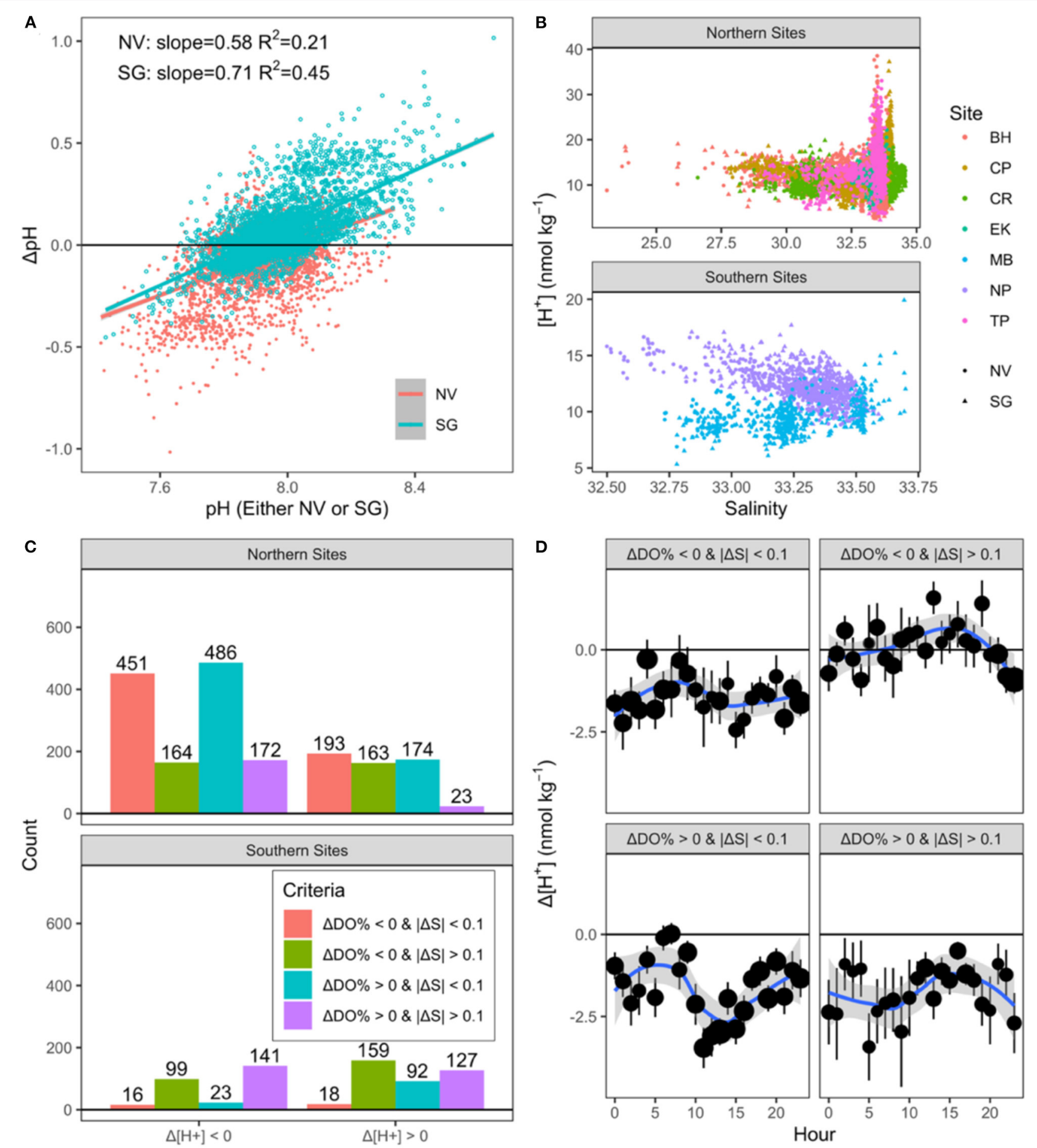

FIGURE 1 | Linear correlation $(p<0.001)$ between $\mathrm{pH}$ and $\Delta \mathrm{pH}$ (A). Relationship between salinity and $\left[\mathrm{H}^{+}\right]$, separated by region and site (B). Points in (B) are colored by site, while the shape identifies between "Seagrass" (SG) and "Non-vegetated" (NV) areas. Counts of positive and negative $\Delta\left[\mathrm{H}^{+}\right]$hourly averages, separated by region and by the threshold criteria described in the legend (C). Hourly climatology (D) of $\Delta\left[\mathrm{H}^{+}\right]$, separated by the same criteria as (C), with point size scaled to represent sample size. 
differences in $\mathrm{pH}$ on the same order as the mean $\Delta \mathrm{pH}$ in $\mathrm{R} 21$ (mean $\Delta \mathrm{pH}=0.07 \pm 0.008$ ). It is therefore only appropriate to ascribe non-zero $\Delta \mathrm{pH}$ to a "seagrass" driver when $|\Delta S|(|\Delta S|$ $\left.=\left|S_{\text {seagrass }}-S_{\text {nonvegetated }}\right|\right)$ is low enough to suggest minimal mixing effects, and we suggest a threshold of 0.1 for this dataset. Considering both of these conditions, we have re-analyzed the R21 dataset, (1) using $\Delta\left[\mathrm{H}^{+}\right]$rather than $\Delta \mathrm{pH}$ (for the reason above), and (2) separating $\Delta\left[\mathrm{H}^{+}\right]$measurements by cases where $\Delta \mathrm{DO} \%$ and $|\Delta S|$ are above or below thresholds of $0 \%$ and 0.1 , respectively.

Consistent with R21, we find that hourly average $\Delta[\mathrm{H}+]$ was indeed negative (i.e., positive $\Delta \mathrm{pH}$ ) marginally more often than chance alone would dictate, at $\sim 62 \%$ of the time across all sites (1,552 out of 2,501 hourly averages: Figure 1C). Approximately $38 \%$ of these potential "OA amelioration" events (negative $\left.\Delta\left[\mathrm{H}^{+}\right]\right)$coincided with both positive $\Delta \mathrm{DO} \%$ and $|\Delta \mathrm{S}|<0.1$ in the northern sites (left blue bars, top), suggesting seagrass ecosystem metabolism as a plausible cause. This fraction was only $8 \%$ in the southern sites (left blue bars, bottom). Across all sites, another $\sim 20 \%$ of these negative $\Delta\left[\mathrm{H}^{+}\right]$cases occurred when $\Delta \mathrm{DO} \%$ was positive but $\Delta \mathrm{S}$ suggested a mixing effect on $\mathrm{pH}$ (left purple bars). To summarize, approximately two thirds (67\%) of these $\Delta\left[\mathrm{H}^{+}\right]<0$ excursions across all sites occurred when $\Delta \mathrm{DO} \%$ was negative or when $|\Delta S|$ was $>0.1$ (left purple, red and green bars in Figure 1C), supporting our claim that local $\mathrm{pH}$ increases were most often caused by factors other than seagrass photosynthetic $\mathrm{CO}_{2}$ uptake. A seasonal analysis (Northern sites only) indicates that this feature is also persistent throughout the year (not shown in Figure 1C), and is therefore unlikely to be related to periods of seagrass senescence or growth.

That negative $\Delta\left[\mathrm{H}^{+}\right]$and $\Delta \mathrm{DO} \%$ so often coincide is an intriguing feature of the R21 dataset. High allochthonous and autochthonous organic carbon subsidies in seagrass meadows enhance aerobic respiration (decreasing $\triangle \mathrm{DO} \%$ ) but also stimulate anaerobic respiratory pathways in the sediment like nitrate and sulfate reduction that generate alkalinity and thereby buffer aerobic respiratory $\mathrm{CO}_{2}$ inputs. As a result, DO and $\mathrm{pH}$ variations are often decoupled in seagrass meadows (Van Dam et al., 2019), especially when benthic alkalinity inputs are apparent (Miller and Kelley, 2021). Net alkalinity production in the sediments, when bottom waters are oxygenated, can occur through denitrification or through the burial of reduced products of sulfate and iron reduction $\left(\mathrm{FeS}_{\mathrm{x}}\right)$. While these and other alkalinity sources are likely to affect seagrass ecosystem carbon chemistry (Van Dam et al., 2019; Akhand et al., 2020), even in the same field sites occupied in R21 ("MB"; Kindeberg et al., 2020), such sediment-water alkalinity fluxes are only just now explicitly being incorporated into "blue carbon" budgets (Reithmaier et al., 2021 ). Still, this leaves only 509 , or $\sim 20 \%$, of all measurements as potentially related to a seagrass photosynthesis effect (Figure 1C, left teal bars), far below the $65 \%$ claimed in R 21 . This is partially balanced by the count of positive $\Delta\left[\mathrm{H}^{+}\right]$measurements where $\Delta \mathrm{DO} \%$ is also below our threshold ( $n=211$, right red bars). That daytime $\mathrm{pH}$ increases are roughly balanced by low nighttime $\mathrm{pH}$ is in line with recent findings that seagrass net metabolism is typically close to zero, when assessed over a full diel cycle (Perez et al., 2018; Asmala et al., 2019; Van Dam et al., 2019; Akhand et al., 2020; Berger et al., 2020).
Lastly, the claim that OA amelioration persists over-night and "up to 21 days" should be revisited, for two main reasons. First, all R21 sites are mixed semidiurnal, with low tides $\sim 0 \mathrm{~m}$ (Supplementary Figure 1, R21) and tidal ranges of $2-5 \mathrm{~m}$, indicating complete replacement of the water column every tidal cycle. Water residence time shapes buffering in tidal seagrasses (Ribas-Ribas et al., 2011; Koweek et al., 2018), and in this case prevents the products of daytime photosynthesis from evading tidal flushing and persisting overnight. Such tidal impacts on seagrass carbon cycling are consistent with a global metaanalysis showing that tidal mixing drives energy budgets (hence carbon budgets) out of balance in these systems (Van Dam et al., 2021). Secondly, apparent daytime proton consumption $\left(-\Delta\left[\mathrm{H}^{+}\right]\right)$did often coincide with $+\Delta \mathrm{DO}$ and $|\Delta \mathrm{S}|<0.1$, consistent with seagrass ecosystem photosynthesis (Figure 1D; bottom left panel). However, $-\Delta\left[\mathrm{H}^{+}\right]$also frequently coincided with other scenarios (Figure 1D; top left and bottom right panels), suggesting that $-\Delta\left[\mathrm{H}^{+}\right]$was a general feature of the dataset regardless of daytime seagrass productivity, as argued by R21.

The authors conclude that seagrass-mitigation of low $\mathrm{pH}$ should be used as a management tool combatting coastal OA. Public audiences reading this will expect that support of seagrass restoration/protection will result in co-beneficial ecosystem services of OA-mitigation. However, the authors make a fundamental error in their treatment of $\mathrm{pH}$ by calculating and interpreting variations in $\Delta \mathrm{pH}$. This is mathematically incorrect, and our closer re-analysis of R21 data using a more appropriate scale $\left(\Delta\left[\mathrm{H}^{+}\right]\right)$leads us to question the key claims of $\mathrm{R} 21$ regarding $\mathrm{OA}$-amelioration. Our re-analysis indicates that any $\mathrm{OA}$-amelioration effect due to seagrass aerobic metabolism was much more limited in spatial and temporal scope than suggested in R21. While seagrass restoration or protection is worthy in its own right, it may therefore fall short of the $\mathrm{pH}$-mitigation effect promised in R21.

\section{AUTHOR CONTRIBUTIONS}

BV conceptualized this work and conducted the data analysis. CL, MZ, MR-R, HW, and HT contributed equally to manuscript writing and revising. All authors contributed to the article and approved the submitted version.

\section{FUNDING}

This work was funded by Deutscher Akademischer Austauschdienst (German Academic Exchange Service) -57429828 (to BV and HT).

\section{ACKNOWLEDGMENTS}

We thank Wiley Evans for his detailed and valuable input during the preparation of this manuscript. Thanks also to Aurora Ricart for the open exchange of information and helpful discussions of their dataset. Code for data analysis and figure generation is available at: https://rpubs.com/bvandam/SG_pH_reanalysis. 


\section{REFERENCES}

Akhand, A., Watanabe, K., Chanda, A., Tokoro, T., Chakraborty, K., Moki, H., et al. (2020). Lateral carbon fluxes and $\mathrm{CO}_{2}$ evasion from a subtropical mangrove-seagrass-coral continuum. Sci. Tot. Environ. 752:142190. doi: 10.1016/j.scitotenv.2020.142190

Asmala, E., Gustafsson, C., Krause-Jensen, D., Norkko, A., Reader, H., Staehr, P. A., et al. (2019). Role of eelgrass in the coastal filter of contrasting baltic sea environments. Estuar. Coast. 7, 1882-1895. doi: 10.1007/s12237-01900615-0

Berger, A. C., Berg, P., McGlathery, K. J., and Delgard, M. L. (2020). Long-term trends and resilience of seagrass metabolism: a decadal aquatic eddy covariance study. Limnol. Oceanogr. 2020, 1-16. doi: 10.1002/lno.11397

Fassbender, A. J., Orr, J. C., and Dickson, A. G. (2021). Technical note: interpreting pH changes. Biogeosciences 18, 1407-1415. doi: 10.5194/bg-18-1407-2021

Kindeberg, T., Bates, N. R., Courtney, T. A., and Cyronak, T. (2020). Porewater carbonate chemistry dynamics in a temperate and a subtropical seagrass system. Aquat. Geochem. 8:123456789. doi: 10.1007/s10498-020-09378-8

Koweek, D. A., Zimmerman, R. C., Hewett, K. M., Gaylord, B., Giddings, S. N., Nickols, K. J., et al. (2018). Expected limits on the ocean acidification buffering potential of a temperate seagrass meadow. Ecol. Appl. 28, 1694-1714. doi: 10.1002/eap.1771

Miller, C. A., and Kelley, A. L. (2021). Alkalinity cycling and carbonate chemistry decoupling in seagrass mystify processes of acidification mitigation. Sci. Rep. 11:2. doi: 10.1038/s41598-021-92771-2

Perez, D. I., Phinn, S. R., Roelfsema, C. M., Shaw, E., Johnston, L., and Iguel, J. (2018). Primary production and calcification rates of algae-dominated reef flat and seagrass communities. J. Geophys. Res. Biogeosci. 123, 2362-2375. doi: 10.1029/2017JG004241

Reithmaier, G. M. S., Johnston, S. G., Junginger, T., Goddard, M. M., Sanders, C. J., Hutley, L. B., et al. (2021). Alkalinity production coupled to pyrite formation represents an unaccounted blue carbon sink. Glob. Biogeochem. Cycles 1, 1-20. doi: 10.1002/essoar.10503988.1
Ribas-Ribas, M., Hernández-Ayón, J. M., Camacho-Ibar, V. F., Cabello-Pasini, A., Mejia-Trejo, A., Durazo, R., et al. (2011). Effects of upwelling, tides and biological processes on the inorganic carbon system of a coastal lagoon in Baja California. Estuar. Coast. Shelf Sci. 95, 367-376. doi: 10.1016/j.ecss.2011.09.017

Ricart, A. M., Ward, M., Hill, T. M., Sanford, E., Kroeker, K. J., Takeshita, Y., et al. (2021). Coast-wide evidence of low $\mathrm{pH}$ amelioration by seagrass ecosystems. Glob. Change Biol. 2021, 1-12. doi: 10.1111/gcb.15594

Van Dam, B., Polsenaere, P., Barreras-Apodaca, A., Lopes, C., Sanchez-Mejia, Z., Tokoro, T., et al. (2021). Global trends in air-water $\mathrm{CO}_{2}$ exchange over seagrass meadows revealed by atmospheric Eddy Covariance. Glob. Biogeochem. Cycles 35:e2020GB006848. doi: 10.1029/2020GB006848

Van Dam, B. R., Lopes, C., Osburn, C. L., and Fourqurean, J. W. (2019). Net heterotrophy and carbonate dissolution in two subtropical seagrass meadows. Biogeosciences 16, 4411-4428. doi: 10.5194/bg-16-4411-2019

Conflict of Interest: The authors declare that the research was conducted in the absence of any commercial or financial relationships that could be construed as a potential conflict of interest.

Publisher's Note: All claims expressed in this article are solely those of the authors and do not necessarily represent those of their affiliated organizations, or those of the publisher, the editors and the reviewers. Any product that may be evaluated in this article, or claim that may be made by its manufacturer, is not guaranteed or endorsed by the publisher.

Copyright (C) 2021 Van Dam, Lopes, Zeller, Ribas-Ribas, Wang and Thomas. This is an open-access article distributed under the terms of the Creative Commons Attribution License (CC BY). The use, distribution or reproduction in other forums is permitted, provided the original author(s) and the copyright owner(s) are credited and that the original publication in this journal is cited, in accordance with accepted academic practice. No use, distribution or reproduction is permitted which does not comply with these terms. 